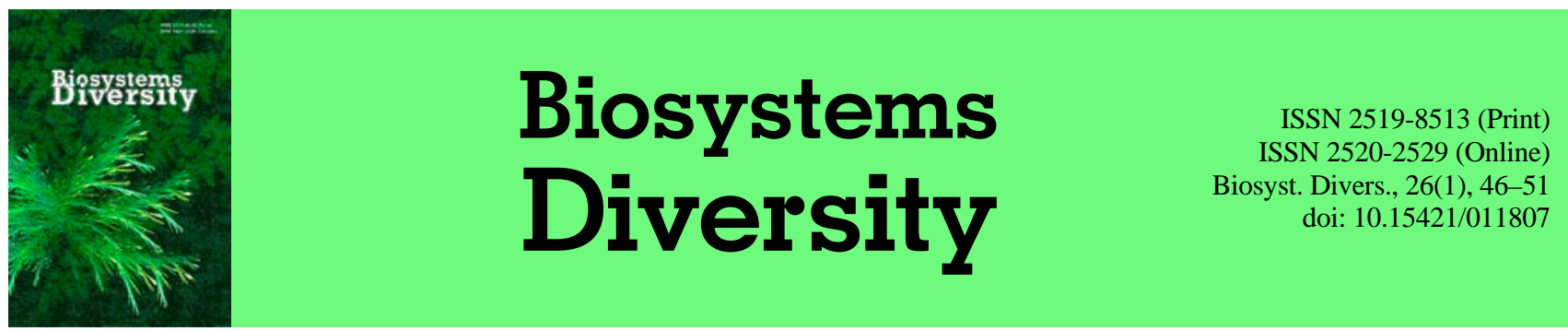

\title{
Influence of the herbaceous layer and litter depth on the spatial distribution of litter macrofauna in a forest plantation
}

\author{
L. I. Faly, V. V. Brygadyrenko \\ Oles Honchar Dnipro National University, Dnipro, Ukraine
}

Article info

Received 04.01.2018

Received in revised form 12.02.2018

Accepted 15.02.2018

Oles Honchar Dnipro National University, Gagarin Ave., 72,

Dnipro, 49010, Ukraine. Tel. +38-050-939-07-88. E-mail: brigad@ua.fm

Faly, L. I., \& Brygadyrenko, V. V. (2018). Influence of the herbaceous layer and litter depth on the spatial distribution of litter macrofauna in a forest plantation. Biosystems Diversity, 26(1), 46-51. doi: 10.15421/011807

The litter invertebrate community consists of species from different size, trophic and taxonomic groups. The distribution of the animal population of the litter horizon depends upon many factors, especially the content of the phytocoenosis, the projective herbaceous plant cover, moisture, litter thickness and the soil texture. This article analyses the variability of the main characteristics of litter invertebrate communities (total number, number of species, diversity according to the ShannonWiener and Pielou indices) on plots with different herbaceous plant composition and cover in plantations of Robinia pseudoacacia L. in the South steppe zone of Ukraine (territory of the “Tiligulsky” Regional Landscape Park). The taxonomic structure of the litter communities in the Robinia plantation was dominated by predatory groups of invertebrates (Carabidae, Aranea, Formicidae). The abundance of Julidae, Isopoda, Silphidae and Staphylinidae was relatively low. The studied forest plots were characterized by the simplified size structure of the litter macrofauna. The absence of species with body length of 16-20 mm and length over $20 \mathrm{~mm}$ indicates damage to the most significant trophic chains. The forest belt studied is in a highly disturbed condition, the plots being dominated by steppe species of herbaceous plants. The analyzed factors (diversity and extent of cover of herbaceous plants) do not determine the structure of the litter macrofauna community but affect it indirectly: a slight increase in the total number of invertebrates was observed in areas with minimal and maximum number of species of herbaceous plants. The relationship between the abundance of invertebrates and the percentage of herbaceous plant cover is manifested insignificantly. We noted a tendency for the number of invertebrate species to decrease along the gradient of herbaceous plant cover due to the concentration of dominant predatory species which exterminate other trophic groups of macrofauna.

Keywords: spatial distribution structure; mosaic distribution pattern; soil fauna; biodiversity; forest litter

\section{Introduction}

Litter invertebrates in forests undergo continuous redistribution in response to changes in temperature, moisture, abundance and quality of food objects, abundance of predators and parasites. All the abovementioned characteristics change over time (long-term, seasonal, and daily cyclic dynamics, which have significant fluctuations, caused by random variations in weather conditions). As a result, the number of invertebrates on a particular plot changes randomly. It is impossible to predict in advance for any moment of time at a given plot which of the factors will operate within the optimum range and which at an extreme range for any given species of invertebrate (Doblas-Miranda et al., 2009; Brygadyrenko, 2015a).

The factors which determine the distribution and structure of litter macrofauna communities have not yet been fully studied. A number of studies in different geographical zones, on different territories within natural ecosystems and in urban landscapes show that the formation of the structure of litter invertebrate communities involves a complex of dynamically related factors. The primary factors are considered to be the microclimatic conditions of a biotope, thickness and qualitative composition of the litter, which depends from the character of the vegetation and relations between trophic groups, and the soil texture (Decaëns et al., 1998; Scheu \& Schaefer, 1998; Kazemi et al., 2009; Bozhko, 2014; Ohta et al., 2014; Morgado et al., 2015).

Within the conditions of artificial forest plantations a very different composition of invertebrate community is formed from that of natural forests. These differences manifest themselves as a change in the sequence of domination by taxa, decrease in total number of species, high variability of the seasonal species composition. The regime of increased lighting in artificial forests, which determines the compound of species in the herbaceous and shrub layers, causes steppe species of herbaceous plants and invertebrates to penetrate below the canopy. Plantations with open canopies undergo full or partial disappearance of woodland plants because the reduced tolerance of forest species of herbaceous plants and invertebrates to lack of moisture (Bonham et al., 2002; Ikeda et al., 2005; Barsoum et al., 2013; Brygadyrenko, 2015b).

This type of complex scheme of interaction between the herbaceous layer and the invertebrate community is seen in artificial plantations of Robinia pseudoacacia L. in the South steppe zone, and it causes a practically complete substitution of forest species by steppe and habitat generalist species (Brygadyrenko, 2015; Listopadsky, 2015). Competition between species which are respectively the elements of steppe and forest cycles of substance and energy exchange, is followed by formation of a patchy spatial structure of the herbaceous layer in the forest plantations, and, on the other hand, by natural re-distribution of individuals of different litter macrofauna species.

Interaction of herbaceous plants with litter macrofauna has been studied in natural forests of Ukraine's steppe zone (Brygadyrenko, 2015b) and in poplar plantations within city parks (Faly \& Brygadyrenko, 2014). The patterns of spatial distribution of litter macrofauna in Robinia woodland belts of the Southern subzone of Ukraine's steppe zone have not been studied up to now. Planted forests in these territories are of interest on account of the constraints imposed by the highly contrasting conditions of the surrounding environment, characterized by low moisture and high levels of insolation, as exemplified by the “Tiligulsky” Regional Landscape Park.

This article investigates the following hypotheses: (1) the diversity of herbaceous plants determines the structure of the litter macrofauna; 
(2) the projective cover of herbaceous plants significantly changes the main characteristics of litter invertebrate communities (total number, species diversity, diversity according to the Shannon-Wiener and Pielou indexes). The article's objective is to evaluate the variability of litter invertebrate communities on plots with different composition and projective cover of herbaceous plants in Robinia pseudoacacia L. plantations.

\section{Materials and methods}

The invertebrates were collected in June of 2014 from a woodland shelterbelt (N 46.9207", E 31.0908') in the "Tiligulsky" Regional Landscape Park (in the vicinity of Tashyno Berezans'ke village, Nikolaevs'ka oblast' of Ukraine). A 60 year old plantation of $R$. pseudoacacia L. was studied. The shrub layer was insignificantly represented in the site's plant community (density - 10\%). In the herbaceous layer the dominant plants were: Festuca sp. (10-60 \%), Elytrigia repens L. (5-60\%), Bromus squarrosus L. (5-60\%), Galium mollugo L. (5-50\%), Marrubium praecox Janka (5-40\%), Artemisia austrica L. (5-30\%).

For monitoring the invertebrates, the method of manual sifting of the litter was used. The research plot $\left(80 \mathrm{~m}^{2}\right)$ was divided into $1 \times 1 \mathrm{~m}$ squares. The $1 \mathrm{~m}^{2}$ squares differed in content of litter, compound of species and number of herbaceous plants. Before the litter was collected for sifting, a description of the herbaceous cover of each $1 \mathrm{~m}^{2}$ square was made, evaluating the cover (\%) of each species of herbaceous plant, and the juvenile and immature phases of shrub plants. Before collecting litter, the higher parts of the herbaceous plants were carefully cut with secateurs, in order to minimize disturbance to the litter and to avoid causing vertical or horizontal migration of the litter macrofauna.

The numerical assessment of the litter invertebrates was done using the best known indexes (Shannon-Wiener, Pielou). Statistical analysis of the results was made in Statistica 8.0 (StatSoft Inc., USA). The differences between the selections were evaluated using ANOVA, they were considered significant at $\mathrm{P}<0.05$. The diagrams show median, $25-75 \%$ quartiles, maximum and minimum values, and in certain cases, extremes.

\section{Results}

The dominant groups in the taxonomic structure of the "Tiligulsky" Robinia plantation's litter communities were predatory groups of invertebrates. The most numerous groups on the studied area were Cara-

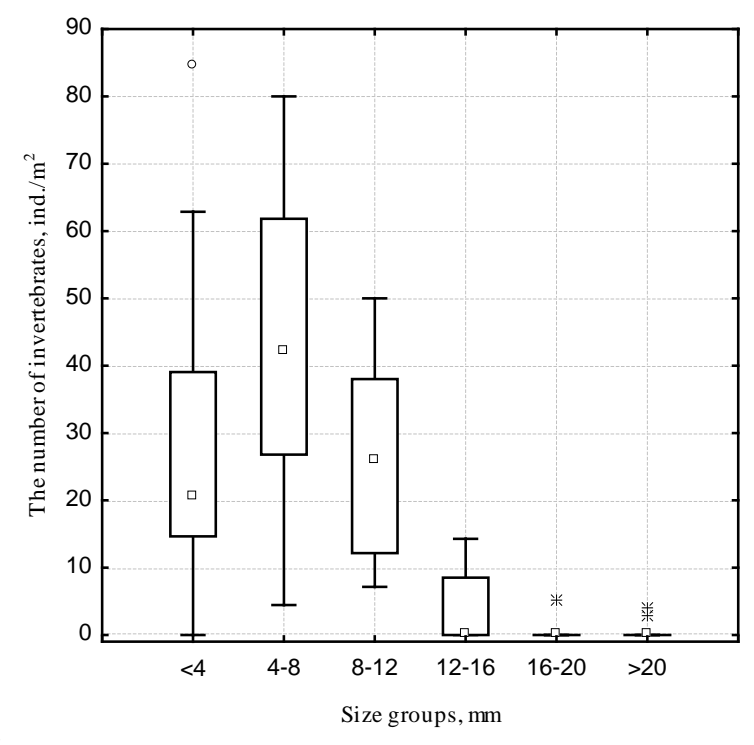

bidae, Aranea and Formicidae. The populations of Julidae, Isopoda, Silphidae and Staphylinidae, which are typical for natural types of forests in Ukraine's steppe zone, were relatively low in the planted shelterbelt. Among typical saprophages, the dominant species were Porcellio scaber Latreille, 1804 and Rossiulus kessleri (Lohmander, 1927).

The size structure of invertebrate communities reflects the extent of exploitation of an ecosystem's trophic resources by litter invertebrates. A community which contains all size groups is considered stable. The Robinia plantation in the "Tiligulsky" Regional Landscape Park was characterized by the simplified size structure of the litter macrofauna. The dominating group was invertebrates with body length of 4-8 mm (abundance reached 80 individuals $/ \mathrm{m}^{2}$ ). This group is more abundant than other types in artificial forests in the steppe zone (Faly \& Brygadyrenko, 2014). The abundance of litter invertebrates with the shortest body length (less than $4 \mathrm{~mm}$ ) reached a relatively high value, at 63 individuals $/ \mathrm{m}^{2}$. The high density of macrofauna belonging to this size group indicates a stable temperature regime and moisture conditions in the course of the season. However, the absence of species with body length of 16-20 $\mathrm{mm}$ and over $20 \mathrm{~mm}$ indicates disturbance to the most significant trophic chains, for ultimately large invertebrates are a food source for predatory vertebrates (Fig. 1a). The size structure of the litter macrofauna community did not change along the gradient of herbaceous vegetation cover (Fig. 1b). The woodland belt is in a highly vulnerable condition (as a woodland habitat), the plots were dominated by steppe species of herbaceous plants.

The total number of litter macrofauna in acacia plantations fluctuates across a wide range. The domination of one or two species of invertebrates in a particular forest plot causes rapid increase of population (54 individuals $/ \mathrm{m}^{2}$ ), which is higher than the average indicator for the given type of forest ( 23 individuals $/ \mathrm{m}^{2}$ ). This characteristic (for most sample plots) significantly differs (in poverty of fauna) from the same indicators in natural floodplain and ravine broad-leaf forests of Ukraine's steppe zone. A statistically significant increase in the total number of invertebrates was seen in the plots with minimum and maximum number of herbaceous plant species (Fig. 2a). The relationship between litter invertebrate abundance and the percentage of herbaceous plant cover is manifested insignificantly. A more revealing factor which causes the increase and decrease of macrofauna populations is the thickness of forest litter. Insufficient moisture in the conditions of artificial forests in South Ukraine causes litter invertebrates to migrate to limited areas with optimum moisture and lowering of the microrelief and a raised percentage of herbaceous plant cover (Brygadyrenko, 2016).

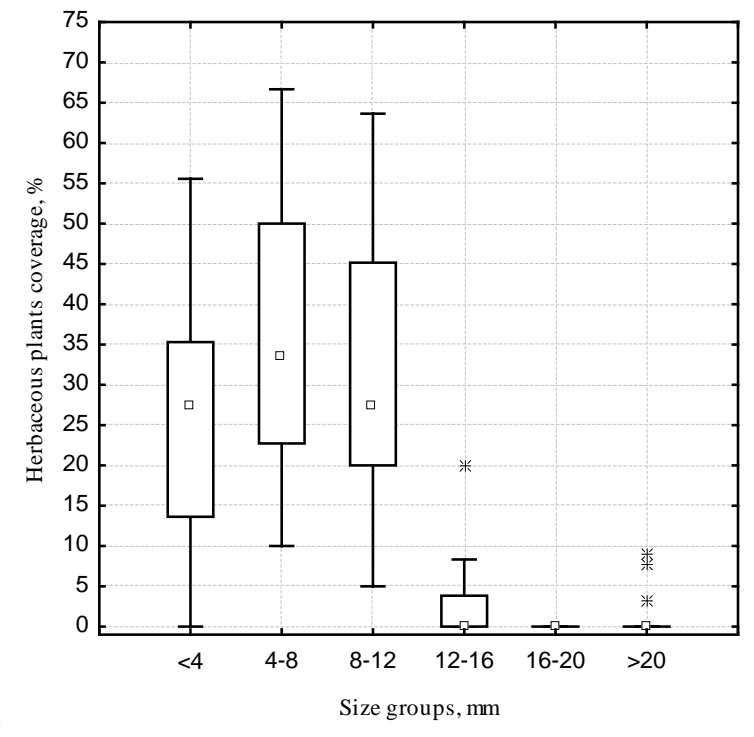

Fig. 1. The number of separate size groups of litter macrofauna $(a)$ in their preferred herbaceous layer conditions $(b)$ in the forest ecosystem

On the studied plots, we observed an insignificant increase of invertebrate species in relation to the number of herbaceous plant species (Fig. 3a), which is explained by the increase of the species which inhabit the herbaceous layer (specialized phytophages). The number of inverte- brate species tends to decrease along the gradient of herbaceous plant cover (Fig. 3b), due to concentration of dominant predatory species of invertebrates (Carabidae, Aranea, Formicidae), which exterminate other trophic groups (phytophages, saprophages). 

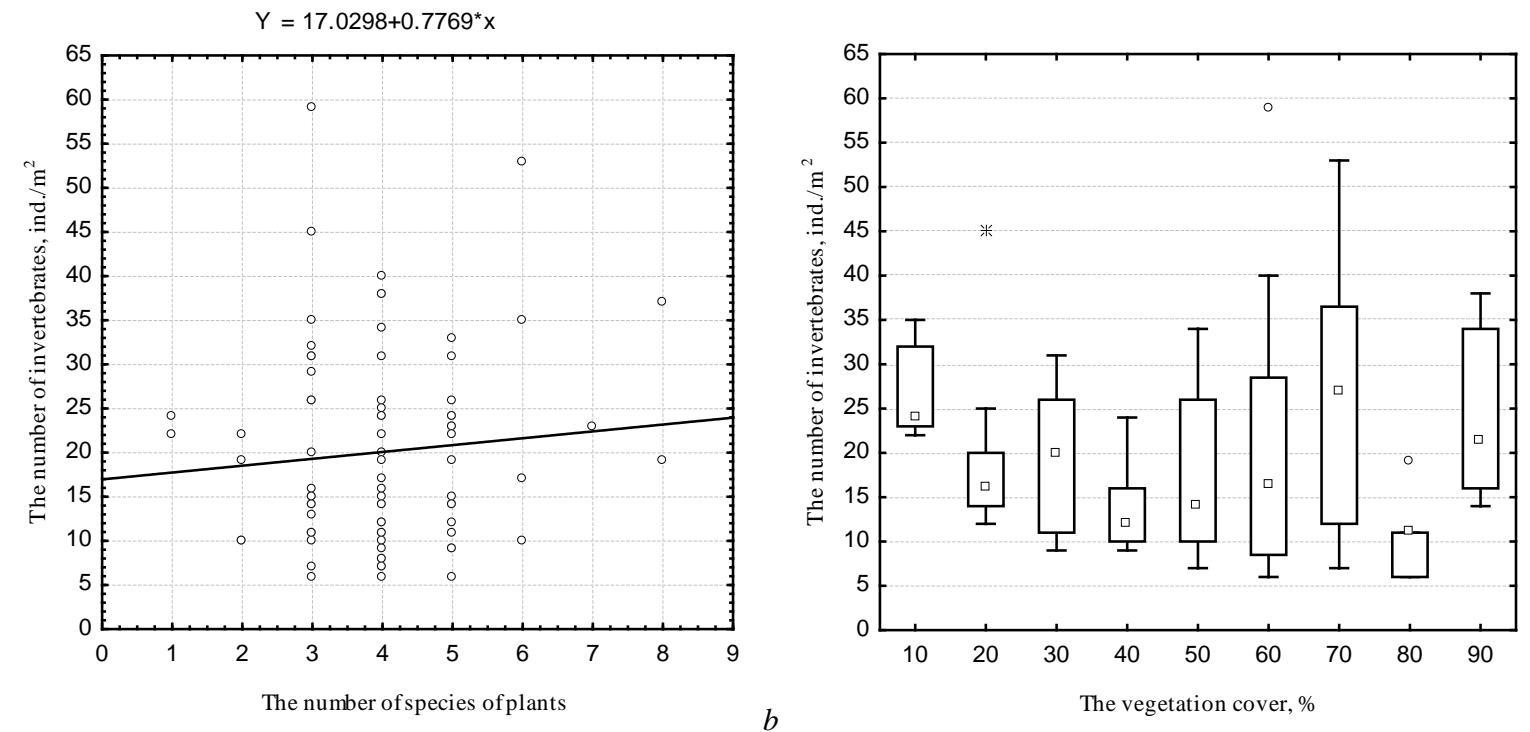

Fig. 2. The relationship between number of litter invertebrates and the number of herbaceous plant species on one sample plot (a) and herbaceous plant cover $(b)$ in the forest ecosystem
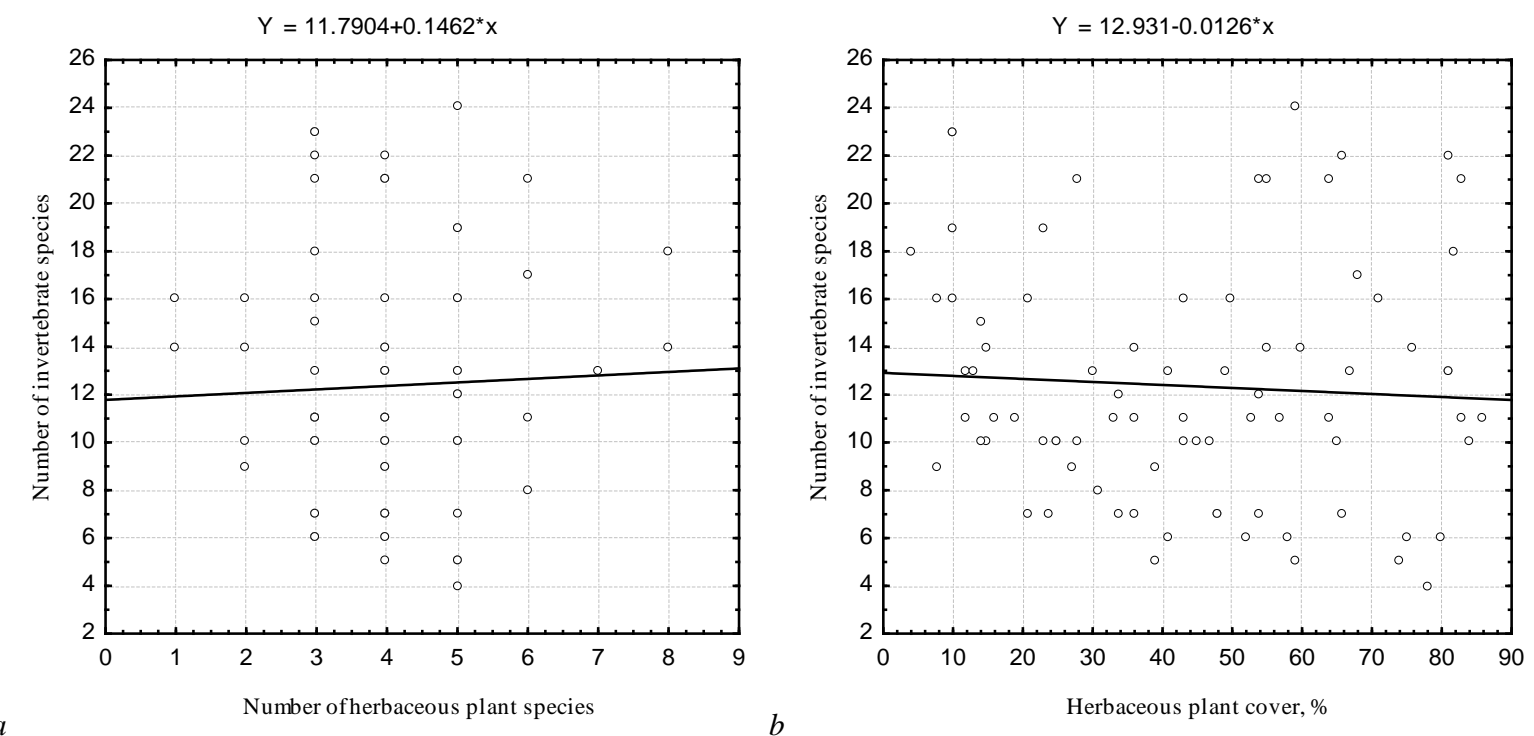

Fig. 3. The relationship between number of litter invertebrate species and the number of herbaceous plant species on one sample plot (a) and herbaceous plant cover $(b)$ in forest ecosystem

The Shannon-Wiener index of biological diversity considers the number of invertebrate species on a sample plot. The number of plant species does not affect the diversity of macrofauna according to Shannon-Wiener, no relationship was found (Fig. 4a). The values of the index remain at a low level for all the plots (3.3 bits). The Pielou index illustrates the extent of species uniformity in numbers, evaluates the absence of dominants in the community. With increase in diversity of herbaceous plants, the values of the Pielou diversity index tend to decrease (from 0.94 bit for one species of plants to 0.91 bit for nine species of plants per $1 \mathrm{~m}^{2}$ ) (Fig. 4b).

A tendency was observed towards decrease in the Shannon-Wiener index (from 3.4 to 3.2 bits) when there was an increase (0-90\%) in the percentage of herbaceous plant cover (Fig. $5 \mathrm{a}$ ). The values of the Pielou diversity index do not change for these characteristics (Fig. 5b).

The Shannon-Wiener index did show a statistically significant change in the macrofauna diversity in relationship to the gradient of herbaceous plant diversity (Fig. 6a). According to the Pielou index, when plant diversity increases, the diversity of litter invertebrates decreases by 0.04 bit (Fig. 6b).

The size structure of the litter macrofauna community did not change in relation to the gradient of herbaceous plant cover. An insignificant increase in the total number of invertebrates was observed in the areas with minimum and maximum diversity of herbaceous plants. An insignificant relationship was shown between the number of litter macrofauna and the percentage of herbaceous plant cover. The diversity of invertebrates on the study plots tended to decrease along the gradient of herbaceous plant cover. The number of plant species did not affect the diversity of the macrofauna according to the Shannon-Wiener index. The values of the Pielou diversity index decrease with higher diversity of herbaceous plants. The values of the Shannon-Wiener index insignificantly decrease with increase in the percentage of herbaceous plant cover (from 3.4 to 3.2 bits). According to Shannon-Wiener the changes of macrofauna diversity along the gradient of herbaceous plant diversity are not statistically significant.

\section{Discussion}

Thus, the suggested hypotheses, concerning (1) the diversity of herbaceous plants determining the structure of litter macrofauna and (2) the projective cover of herbaceous plants significantly affecting the main characteristics of litter invertebrates (the total number, number of species, diversity according to Shannon-Wiener and Pielou) were not 
proved. We observed that the diversity of invertebrates tends to decrease along the gradient of projective herbaceous plant cover due to concentration of dominant species of predatory invertebrates (Carabidae, Aranea, Formicidae), which exterminate other trophic groups of macrofauna. However, an insignificant increase in invertebrate diversity was observed on the plots with high diversity of herbaceous plants, which is explained by increase in percentage of specialized phytophages.

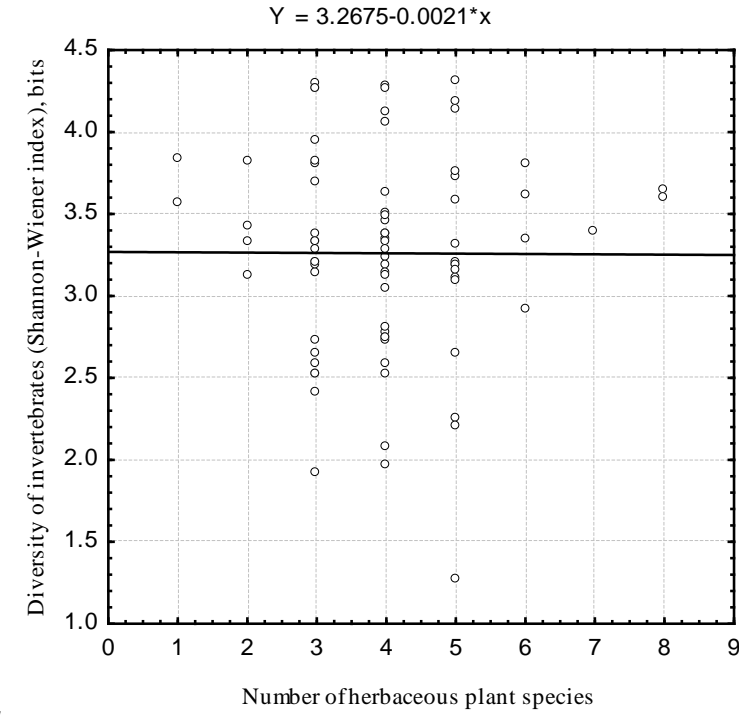

$a$

Fig. 4. The relationship between Shannon-Wiener ( $a$ ) and Pielou $(b)$ diversity indexes of litter macrofauna

Fig. 4. The relationship between Shannon-Wiener $(a)$ and Pielou $(b)$ diversity indexes
and the number of herbaceous plant species on a sample plot
The analyzed factors (diversity and herbaceous plant cover) do not determine the structure of litter macrofauna community, though they may well affect it indirectly: we observed an insignificant increase in the total number of invertebrates on the plots with minimum and maximum diversity of herbaceous plants. The relationship between the abundance of invertebrates and the percentage of herbaceous plant cover was manifested insignificantly.

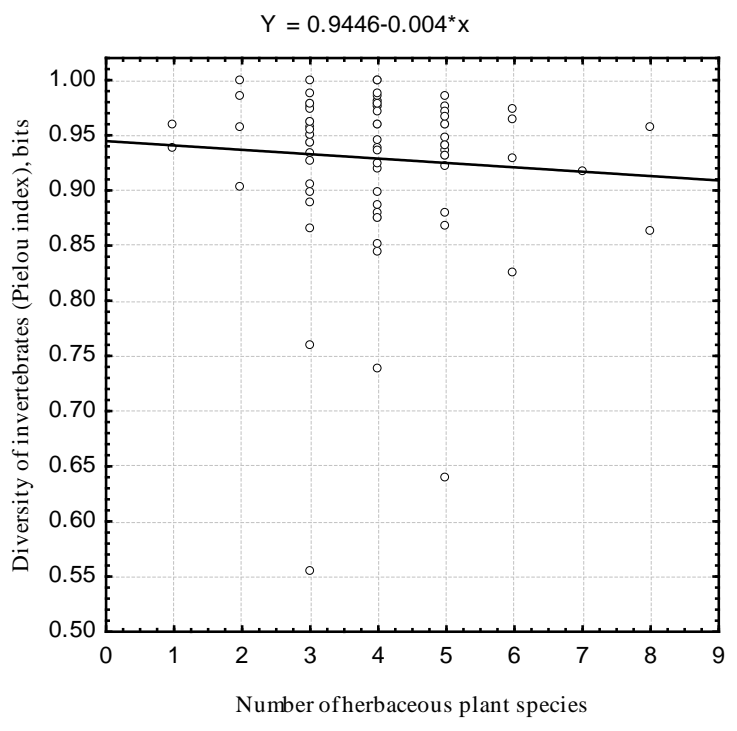

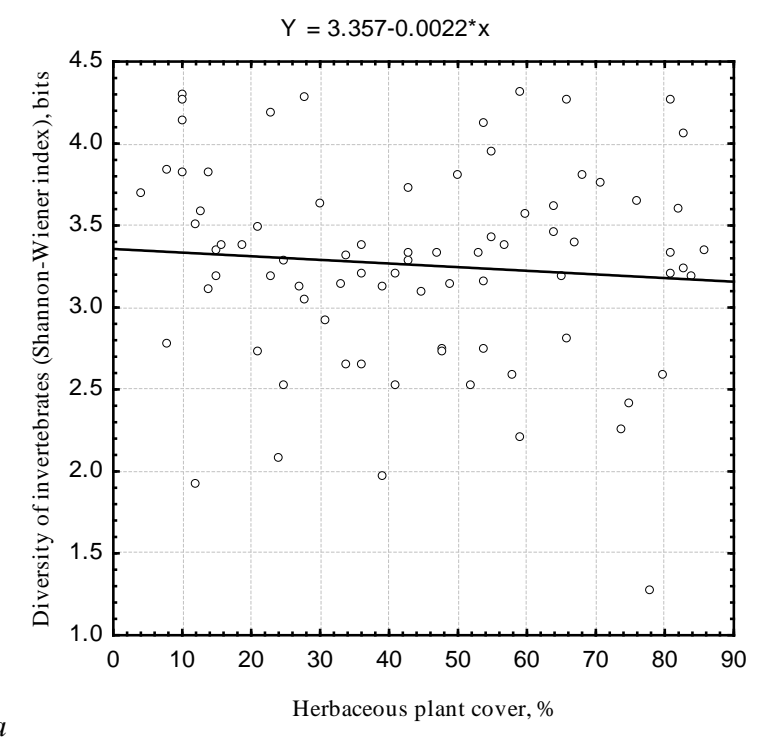

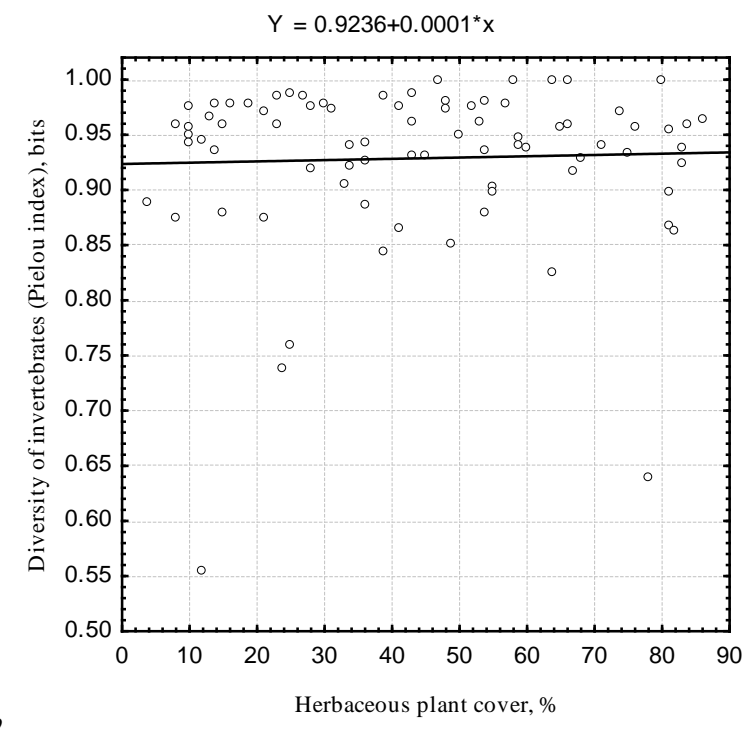

Fig. 5. The relationship between Shannon-Wiener ( $a$ ) and Pielou $(b)$ diversity indexes of litter macrofauna and herbaceous plant cover on a certain sample plot

The mosaic structure of the habitat conditions (due to variations in moisture, lighting, distribution of vegetation, trophic resources) determines the coexistence of invertebrates of different taxonomic, trophic and size groups in any single territory. Individuals of certain species can tolerate the presence or absence of one another, but more often they interact (Koivula et al., 1999; Marko et al., 2004; Hawes et al., 2013; Brygadyrenko, 2016) positively (for example, predators move to places with maximum concentration of prey, saprophages to places with accumulations of vegetative detritus) or negatively (for example, many species of invertebrates avoid places highly populated with ants). The distributional character of predatory litter invertebrates determines the populations of some groups of soil macrofauna, primarily Lumbricidae. The interrelationship between soil and litter invertebrates is seen not only in the formation of trophic chains. A more important function is their part in the zoogenous cycle of chemical elements in the processes of soil formation (Baljuk et al., 2014; Kulbachko et al., 2014; Shtirts, 2015).

The complex network of interaction of elements (individuals of different invertebrate species) on the surface of soil, in the fallen leaves of forest plantations is affected first of all, by the thickness of the fallen leaves' layer, secondly, by the extent of development and diversity of the herbaceous layer. On the other hand, invertebrates-phytophages consume certain species of herbaceous plants themselves; saprophages, grinding and consuming fallen leaves help the seeds of herbaceous plants to reach the surface of soil, increasing their chances of sprouting; zoophages partly limit the number of phytophage species, and polyphages, often, on the contrary, contribute to the reproduction of suctorial species, which feed on plants' juices (for example, ants and aphids, Diaspididae, cicadas). In a forest ecosystem, just as the herbaceous layer 
affects the fauna of litter invertebrates, changing the hygrothermal regime of a particular area of the earth surface, the invertebrates affect the herbaceous layer, changing the distribution of certain species within it (ants move the seeds of many species of plants, Lygaeidae suck out the seeds of many species of plants, etc.) (Marko et al., 2004; Brygadyrenko, 2015b).

Robinia plantations are characterized by the simplified size structure of the litter macrofauna. The dominant group is invertebrates with body length of $4-8 \mathrm{~mm}$ (up to 80 individuals $/ \mathrm{m}^{2}$ ). The population of the group of invertebrates with the shortest body length (less than $4 \mathrm{~mm}$ ) is relatively high -63 individuals $/ \mathrm{m}^{2}$. However, the absence of species with body length of 16-20 mm and body length of over $20 \mathrm{~mm}$ indicates that the most significant trophic chains are distorted due to the anthropogenic transformation of the ecosystem and seasonal variability in the conditions of existence of litter invertebrates. The size structure of

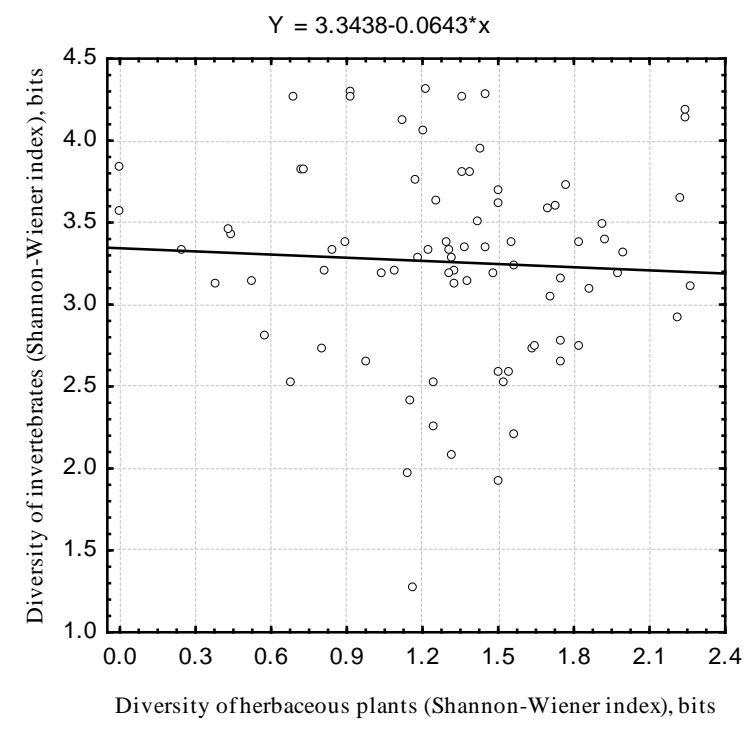

the litter macrofauna community does not change along the gradient of herbaceous plant cover.

The number of plant species does not affect the diversity of invertebrates according to Shannon-Wiener index. The index values (for all plots) are low -3.3 bits. The values of the Pielou diversity index tend to decrease when the diversity of plants increases (from 0.94 bit -1 species of plants to 0.91 bit -9 species of plants per $1 \mathrm{~m}^{2}$ ). An insignificant decrease in the Shannon-Wiener index (from 3.4 to 3.2 bits) was observed when the percentage of herbaceous plant cover increased (0-90\%). The Pielou diversity index does not change in the same conditions. The changes in macrofauna diversity along the gradient of herbaceous plant diversity according to Shannon-Wiener are not statistically significant. According to the Pielou index, the diversity of litter invertebrates insignificantly decreases when the plant diversity increases (by 0.04 bit).

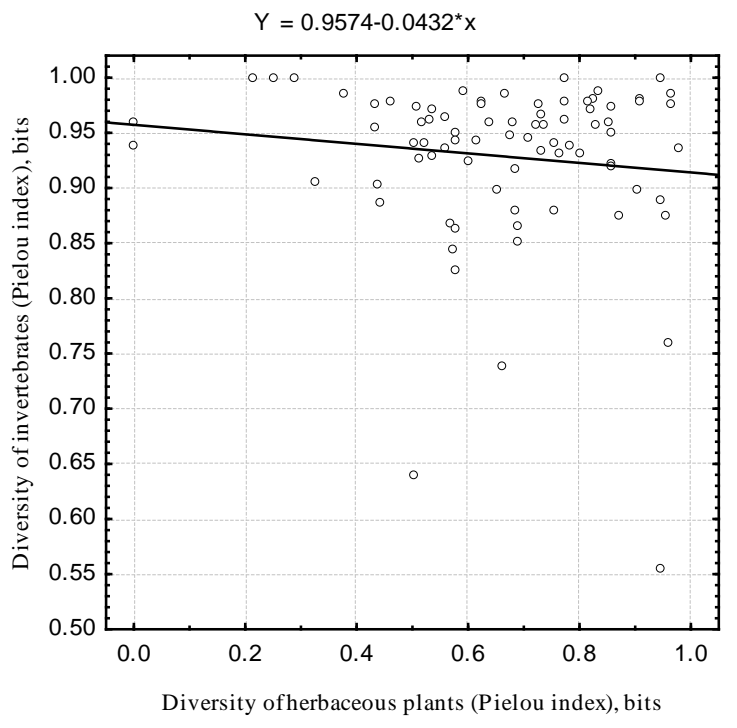

Fig. 6. The relationship between Shannon-Wiener ( $a$ ) and Pielou (b) diversity indexes of forest litter macrofauna and the diversity of herbaceous plants on a sample plot

Other authors (Hansen, 2000; Nakamura et al., 2003; Doblas-Miranda et al., 2009) have usually studied the effect of a wider range of abiotic and biotic factors upon the structure and distribution of soil and litter invertebrates. Statistically significant changes in macrofauna diversity have usually been obtained for forest plots with different moisture and litter thickness, and with different compositions of the studied plantations (Oxbrough et al., 2005, 2010; Pearce \& Venier, 2006). The indirect effect of herbaceous plant diversity upon the main characteristics of community structure of soil-litter invertebrates support the conclusions made by other researchers (Gastine et al., 2003; Hedlund et al., 2003).

\section{Conclusion}

Studies of the connection between the percentage of cover and the diversity of herbaceous plants in Robinia plantations and macrofauna diversity in most cases have shown statistically insignificant changes in the main characteristics of litter macrofauna. Insignificant increase in total number of invertebrates was observed in the gradient of herbaceous plant diversity. A significant relationship between the number of invertebrates and the percentage of herbaceous plant cover was not found. The Shannon-Wiener index values (for all plots) are low (3.3 bits), the plant diversity does not affect the diversity of invertebrates. The Pielou index values insignificantly decrease when the diversity of herbaceous plants increases. With increase in percentage of herbaceous plant cover (0-90\%), the Shannon-Wiener index values tend to decrease; the Pielou index does not change in the same conditions. When the diversity of herbaceous plants increases, the diversity of invertebrates does not change (according to the Shannon-Wiener index) or insignificantly decreases (according to the Pielou index). Thus, the studied factors do not determine the structure of the litter macrofauna community. The obtained results can provide a basis for comparative analysis of the peculiarities of functioning of litter macrofauna in similar forests of different geographic zones, and also can be used for developing measures for improving the stability of artificial forest ecosystems.

\section{References}

Baljuk, J. A., Kunah, O. N., Zhukov, A. V., Zadorozhnaja, G. A., \& Ganzha, D. S. (2014). Adaptivnaya strategiya otbora prob dlya otsenki prostranstvennoj organizatsii soobshhestv pochvennykh zhivotnykh urbanizirovannykh territorij na razlichnykh ierarkhicheskikh urovnyakh [Sampling adaptive strategy and assessment of spatial organisation of soil animal communities at various hierarchical levels of urbanised territories]. Biological Bulletin of Bogdan Chmelnitskiy Melitopol State Pedagogical University, 4(3), 8-33.

Barsoum, N., Fuller, L., Ashwood, F., Reed, K., Bonnet-Lebrun, A.-S., \& Leung, F. (2013). Ground-dwelling spider (Araneae) and carabid beetle (Coleoptera: Carabidae) community assemblages in mixed and monoculture stands of oak (Quercus robur L./Quercus petraea (Matt.) Liebl.) and Scots pine (Pinus sylvestris L.). Forest Ecology and Management, 321, 29-41.

Bonham, K. J., Mesibov, R., \& Bashford, R. (2002). Diversity and abundance of some ground-dwelling invertebrates in plantation vs. native forests in Tasmania, Australia. Forest Ecology and Management, 158(1-3), 237-247.

Bozhko, K. M. (2014). Mikromorfologichni ta fizychni vlastyvosti g'runtiv pivdennyh bajrakiv Dnipropetrovs'koi' oblasti [Micromorphological and physical properties of southern ravine soils in Dnipropetrovsk region]. Visnyk of Dnipropetrovsk University. Biology, Ecology, 22(1), 38-45.

Brygadyrenko, V. V. (2015a). Vplyv umov zvolozhennja ta mineralizacii' g'runtovogo rozchynu na strukturu pidstylkovoi' mezofauny shyrokolystjanyh lisiv stepovoi' zony Ukrai'ny [Influence of moisture conditions and mineralization of soil solution on structure of litter macrofauna of deciduous forests of Ukraine's steppe zone]. Visnyk of Dnipropetrovsk University. Biology, Ecology, 23(1), 50-65 (in Ukrainian). 
Brygadyrenko, V. V. (2015b). Vplyv zimknenosti kron derev i pokryttja trav’janystyh roslyn na strukturu pidstylkovoi' mezofauny shyrokolystjanyh lisiv stepovoi' zony Ukrai'ny [Influence of tree crown density and density of the herbaceous layer on the structure of litter macrofauna of deciduous forests of Ukraine's steppe zone]. Visnyk of Dnipropetrovsk University. Biology, Ecology 23(2), 134-148.

Brygadyrenko, V. V. (2016). Effect of canopy density on litter invertebrate community structure in pine forests. Ekológia (Bratislava), 35(1), 90-102.

Decaëns, T., Dutoit, T., Alard, D., \& Lavelle, P. (1998). Factors influencing soil macrofaunal communities in post-pastoral successions of western France. Applied Soil Ecology, 9(1-3), 361-367.

Doblas-Miranda, E., Sánchez-Piñero, F., \& González-Megías, A. (2009). Different structuring factors but connected dynamics shape litter and belowground soil macrofaunal food webs. Soil Biology and Biochemistry, 41(12), 2543-2550.

Faly, L. I., \& Brygadyrenko, V. V. (2014). Patterns in the horizontal structure of litter invertebrate communities in windbreak plantations in the steppe zone of the Ukraine. Journal of Plant Protection Research, 54(4), 414-420.

Gastine, A., Scherer-Lorenzen, M., \& Leadley, P. W. (2003). No consistent effects of plant diversity on root biomass, soil biota and soil abiotic conditions in temperate grassland communities. Applied Soil Ecology, 24(1), 101-111.

Hansen, R. A. (2000). Effects of habitat complexity and composition on a diverse litter microarthropod assemblage. Ecology, 81(4), 1120-1132.

Hawes, C., Evans, H. F., \& Stewart, A. J. A. (2013). Interference competition, not predation, explains the negative association between wood ants (Formica rufa) and abundance of ground beetles (Coleoptera: Carabidae). Ecological Entomology, 38(4), 315-322.

Hedlund, K., Santa Regina, I., Van der Putten, W. H., Lepš, J., Díaz, T., Korthals, G. W., Lavorel, S., Brown, V. K., Gormsen, D., Mortimer, S. R., Rodríguez Barrueco, C., Roy, J., Smilauer, P., Smilauerová, M., \& Van Dijk, C. (2003). Plant species diversity, plant biomass and responses of the soil community on abandoned land across Europe: Idiosyncracy or above-belowground time lags. Oikos, 103(1), 45-58.

Ikeda, H., Homma, K., \& Kubota, K. (2005). Biotic and abiotic factors affecting the structures of ground invertebrate communities in Japanese cedar dominant forests. Eurasian Journal of Forest Research, 8(1), 1-13.

Kazemi, F., Beecham, S., Gibbs, J., \& Clay, R. (2009). Factors affecting terrestrial invertebrate diversity in bioretention basins in an Australian urban environment. Landscape and Urban Planning, 92(3-4), 304-313.

Koivula, M., Punttila, P., Haila, Y., \& Niemelä, J. (1999). Leaf litter and the smallscale distribution of carabid beetles (Coleoptera, Carabidae) in the boreal forest. Ecography, 22(4), 424-435.
Kulbachko, Y. L., Didur, O. O., Pakhomov, O. Y., \& Loza, I. M. (2014). Trofometabolicheskaja aktivnost' dozhdevyh chervej (Lumbricidae) kak zoogennyj faktor podderzhanija ustojchivosti rekul'tivirovannyh pochv k zagrjazneniju med'ju [Trophic-metabolic activity of earthworms (Lumbricidae) as a zoogenic factor of maintaining reclaimed soils' resistance to copper contamination]. Visnyk of Dnipropetrovsk University. Biology, Ecology, 22(2), 99-104.

Listopadsky, M. A. (2015). Istorija ta suchasnyj stan lisosmuh biosfernoho zapovidnyka "Askanija-Nova" [History and present state of forest belts in the biosphere reserve Askania Nova]. Biological Bulletin of Bogdan Chmelnitskiy Melitopol State Pedagogical University, 5(1), 156-210.

Marko, B., Kiss, K., \& Galle, L. (2004). Mosaic structure of ant communities (Hymenoptera: Formicidae) in Eastern Carpathian marshes: Regional versus local scales. Acta Zoologica Academiae Scientiarum Hungaricae, 50(2), 77-95.

Morgado, R., Ferreira, N. G. C., Cardoso, D. N., Soares, A. M. V. M., Loureiro, S. (2015). Abiotic factors affect the performance of the terrestrial isopod Porcellionides pruinosus. Applied Soil Ecology, 95, 161-170.

Nakamura, A., Proctor, H., \& Catterall, C. P. (2003). Using soil and litter arthropods to assess the state of rainforest restoration. Ecological Management and Restoration, 4(s1), 20-28.

Ohta, T., Niwa, S., Agetsuma, N., \& Hiura, T. (2014). Calcium concentration in leaf litter alters the community composition of soil invertebrates in warmtemperate forests. Pedobiologia, 57(4-6), 257-262.

Oxbrough, A., Irwin, S., Kelly, T. C., \& O’Halloran, J. (2010). Ground-dwelling invertebrates in reforested conifer plantations. Forest Ecology and Management, 259(10), 2111-2121.

Oxbrough, A. G., Gittings, T., O’Halloran, J., Giller, P. S., \& Smith, G. F. (2005). Structural indicators of spider communities across the forest plantation cycle. Forest Ecology and Management, 212(1-3), 171-183.

Pearce, J. L., \& Venier, L. A. (2006). The use of beetles (Coleoptera: Carabidae) and spiders (Araneae) as bioindicators of sustainable forest management: A review. Ecological Indicators, 6(4), 780-793.

Scheu, S., \& Schaefer, M. (1998). Bottom-up control of the soil macrofauna community in a beechwood on limestone: Manipulation of food resources. Ecology, 79(5), 1573-1585.

Shtirts, A. D. (2015). Ekologicheskaya struktura naseleniya pantsimykh kleshhej (kar'er «Osnovnoj», Donetskaya oblast') [The ecological structure of oribatid mites population ('Osnovnoy’ quarry, Donetsk region)]. Biological Bulletin of Bogdan Chmelnitskiy Melitopol State Pedagogical University, 5(2), 16-30. 